\title{
Species of forages utilized by farmers producing halal goats in Bangsamoro Autonomous Region in Muslim Mindanao (BARMM), Philippines
}

\author{
GERALDSON A. NAVARRA ${ }^{1}$, FLORENCE ROY P. SALVAÑA ${ }^{2,3,4, \boldsymbol{v}}$, ELMA G. SEPELAGIO ${ }^{3}$, \\ CARLITO B. SANCHEZ ${ }^{5}$, CYRELLE M. BESANA ${ }^{3}$, LEANNES JAY S. MANCERAS ${ }^{3}$, SULOG G. BRA ${ }^{6}$ \\ ${ }^{1}$ Bureau of Animal Industry (BAI), Cotabato City, Philippines \\ ${ }^{2}$ Graduate School, University of the Philippines Los Baños, College, Laguna, Philippines. "email: rdsalvana @usm.edu.ph \\ ${ }^{3}$ Department of Biological Sciences, College of Arts and Sciences, University of Southern Mindanao, Kabacan, Cotabato, Philippines \\ ${ }^{4}$ Philippine Council for Agriculture, Aquatics and Natural Resources Research and Development (DOST-PCAARRD), Brgy. Timugan, Los Baños, \\ Laguna, Philippines \\ ${ }^{5}$ Department of Clinical Veterinary Sciences College of Veterinary Medicine, University of Southern Mindanao, Kabacan, Cotabato, Philippines \\ ${ }^{6}$ Mindanao State University-Maguindanao, Dinaig, Datu Odin Sinsuat, Maguindanao, Philippines
}

Manuscript received: 2 April 2019. Revision accepted: 10 May 2019.

\begin{abstract}
Navarra GA, Salvaña FRP, Sepelagio EG, Sanchez CB, Besana CM, Manceras LJS, Bra SG. 2019. Species of forages utilized by farmers producing halal goats in Bangsamoro Autonomous Region in Muslim Mindanao (BARMM), Philippines. Asian J Ethnobiol 2: 1-7. Local production of small ruminants necessitates forage assessment because animals are typically fed with locally available plant species. This study was carried out to determine the plants used as forage by raisers producing halal goats in BARMM (Bangsamoro Autonomous Region in Muslim Mindanao). A personal interview with the respondents producing halal goats was conducted, and a questionnaire was used to determine species of forages. A total of eight municipalities were included in the survey, seven of which were from Maguindanao, and one was from Lanao del Sur. Purposive sampling was used in the survey. A total of 47 respondents was interviewed based on the criteria: (i) a believer of Islam, (ii) with 5 to 24 breeders does, and (iii) willingness of the farm owner to participate in the survey. All respondents who fell to these criteria were interviewed. All respondents used forage species, including para grass (Brachiaria mutica), carabao grass (Paspalum conjugatum), ipil-ipil (Leucaena leucocephala), and kakawate (Gliricidia sepium) in all sampling sites. Other species included malunggay (Moringa oleifera), banana (Musa balbisiana), stylo (Stylosanthes humilis), Centrosema (Centrosema pubescens), langka (Artocarpus heterophyllus), pinto peanut (Arachis pintoi), Napier (Pennisetum purpureum), barnyard grass (Echinochloa sp.), Guinea grass (Panicum maximum), Indigofera (Indigofera tinctoria), calliandra (Calliandra calothrysus), katurai (Sesbania grandiflora) and rensonii (Desmodium rensonii). Only eleven percent (11\%) of the respondents utilized improved and domesticated species of forages. Improved and domestic forage species are plants commonly cultivated forage for livestock production. According to the respondents, some plants in open vegetated areas like Erigeron canadensis, Sphagneticola trilobata, Ageratum conyzoides, and Urena lobata were also consumed by goats. The respondents also observed plantrelated toxicosis caused by $C$. pubescens and Urena lobata. Most of the respondents in BARMM are not utilizing improved and domesticated species of forages and rely on locally available forages present in rangeland. Most of them have limited knowledge of the nutritional requirements of goats. There is a need to enhance the understanding of farmers'/breeders' importance of proper forage selection and combination.
\end{abstract}

Keywords: BARMM, forage, goats, halal

\section{INTRODUCTION}

Halal means "permissible," More often than not, it is being applied as a preferred method of animal slaughter (Ibrahim 2011). The term is also used for food and products acceptable to individuals practicing Islam. Farouk et al. (2016) added that it is not just the way animals are slaughtered but also how they are raised. Products labeled as Halal are gaining worldwide attention since it offers an alternative benchmark for food safety, hygiene, and quality assurance (Ambali and Bakar 2014). Among Halal food products, goat meat is one of the most important exported and imported commodities. Established Halal goat meat production facilities are globally located in Islamic countries like Indonesia, Malaysia, Pakistan, and Saudi Arabia. Non-Islamic countries like Singapore are also known to produce Halal goat meat in international trade (EHalal Organization 2010). There have been issues with the authenticity of Halal meat and meat products. Nakyinsige et al. (2012) provided a complete review of these issues. Some of these issues include pork substitution, undeclared blood plasma, the use of prohibited ingredients, pork intestine casings, and non-halal methods of slaughter.

Halal goat production is becoming an economically viable enterprise in the Philippines. Some of the identified regions in the Philippines producing Halal goats include Bangsamoro Autonomous Region for Muslim Mindanao (BARMM) and Region XII (SOCCKSARGEN). Based on the number of goat heads nationwide, $4.55 \%$ of goats are from BARMM. All raisers in the region practiced backyard raising, which constitutes $4.61 \%$ of all backyard raisers in the country. There is a total annual production volume of 
644 metric tons live weight. Based Although the per capita consumption is only $0.21 \mathrm{~kg}$ per year, Halal goats are commonly used by Muslims as a sacrifice in the observance of their faith, especially during religious occasions such as Kanduli, Aqiqah, Ramadan, Eid al-Fitr, and Eid al-Adha, which increase local demands for such commodity during these times.

The Philippine Halal products and services in 2017 were at Php 5.52 billion or $8.73 \%$ of the country's total export. Currently, the Halal goat industry in the Philippines is still in its infancy with minimal annual production, and resources, like forages, are devoted to this are undocumented. Naanep et al. (2009) also observed that goat raisers had inadequate knowledge of various Halal goat production aspects. Knowing this, there is a need to evaluate appropriate and acceptable resources in Halal goat production.

One of the primary resources needed to consider livestock production is forage. Forage assessment is an important consideration, especially in goat raising producing halal meat, since there is no available Halal certified feed concentrate. Moreover, backyard goat raisers commonly use locally available plant species as forage (Nampanzira et al., 2015). The type of forage used for livestock production has nutritional and health implications. Naturally, goats are considered active foragers and browsers. Browse refers to the leaves and twigs from shrubs and trees available to ruminants, such as goats, as feed. Free-forage individual goats can cover a wide area in search of plant materials. The morphology of the goat's mouth enables them to pick small plant parts, choosing the most nutritious available feed. Given the opportunity, goats select over 60 percent of their daily diet from bush and woody perennials and broadleaf plants over herbaceous species (Mkhize et al., 2014). As browsers, goats have been observed to stand on their hind legs and stretch up to browse the leaves. They can also throw their bodies against saplings to bring the tops within reach. Goats are also observed to climb trees or shrubs to consume preferred forage (Schlecht et al. 1999). Pasture areas tend to graze from top to bottom of plants and do not like to feed near the soil. In this type of feeding strategy, goats select grasses when the protein content and digestibility are high. However, they tend to switch to browse when these nutritive values are higher (Bojkovski et al., 2014).

Most backyard goat raisers rely on vegetated areas for forages, and the establishment of improved pasture is minimal (Cosadio et al., 2011). Also, a proper feeding ratio is not observed, and feeding is dependent on available plant species regardless of nutritional value. On the other hand, rangelands, where most farmers are dependent, may be contaminated with plants that are toxic to animals. There have been cases of poisoning, with a considerable mortality rate, due to consuming large amounts of toxic plants (Krueger and Sharp 1978). Moreover, most of the browse species preferred by goats are legumes and contain more tannins. Tannins have adverse and beneficial effects depending on their concentration and nature, animal species, physiological state of the animals, and diet composition (Makkar 2003). Silanikove et al. (1996) concluded that Goats could consume many tannin-rich plants. A tannin level below 5 percent seems to be tolerable for ruminant animals (Ebong 1995). While tannins are best known as an anti-nutritional factor, there is a long list of plant secondary products, such as cyanide, nitrate, fluoroacetate, cyanogenic glycosides, saponins, oxalates, mimosine, and various sterols, present in most browse species (Leng 1997).

As they constitute a significant portion of Halal goat production, forage assessment is necessary to address nutrition and health problems. It is one way to educate Halal goat raisers on proper forage selection and enhance their understanding of the importance of establishing their pasture planted with improved and domesticated species of forages.

\section{MATERIALS AND METHODS}

\section{Location of the study}

The study was conducted in some provinces of the Bangsamoro Autonomous Region in Muslim Mindanao (BARMM) consisting of five predominantly Muslim provinces: Basilan (except Isabela City), Lanao del Sur, Maguindanao, Sulu, and Tawi-Tawi. BARMM traverses two geological territories: Lanao del Sur and Maguindanao (recently Cotabato City included) in southwestern Mindanao and the island areas of Basilan (except Isabela City), Sulu and Tawi-Tawi in the Sulu Archipelago.

Municipalities included in the study were selected using purposive sampling with 2 criteria; (i) barangays (small areas which constitute a municipality) whose municipalities are producing sizeable heads of goats based on the reports provided by the Municipal Agriculture Office, and (ii) consideration of the peace and order condition of the area. Based on records, the two provinces have the highest concentration of goats, Maguindanao and Lanao del Sur. From Maguindanao, 7 municipalities were selected, namely Ampatuan, Datu Odin Sinsuat, North Upi, Sultan Kudarat, Sultan Mastura, Buldon, and Parang and from Lanao del Sur, only the Municipality of Balabagan. Respondents from these municipalities were purposely selected. The location of each respondent's farm was determined, and a map was generated (Figure 1).

\section{Respondents and sampling procedures}

Before sampling, meetings with the Provincial Agricultural Officer, Municipal Agricultural Officers, livestock technicians, and Barangay Chairpersons of the different barangays with the highest concentration of goats were done to discuss the study's rationale.

A total of 47 respondents were interviewed. Sociodemographic information of each respondent was determined, including age, sex, educational attainment, civil status, occupation, and herd size. The selection of respondents in each municipality was based on the following criteria: (i) a believer of Islam (ii) with 5 to 24 breeders does; and (iii) willingness of the farm owner to participate in the survey. 

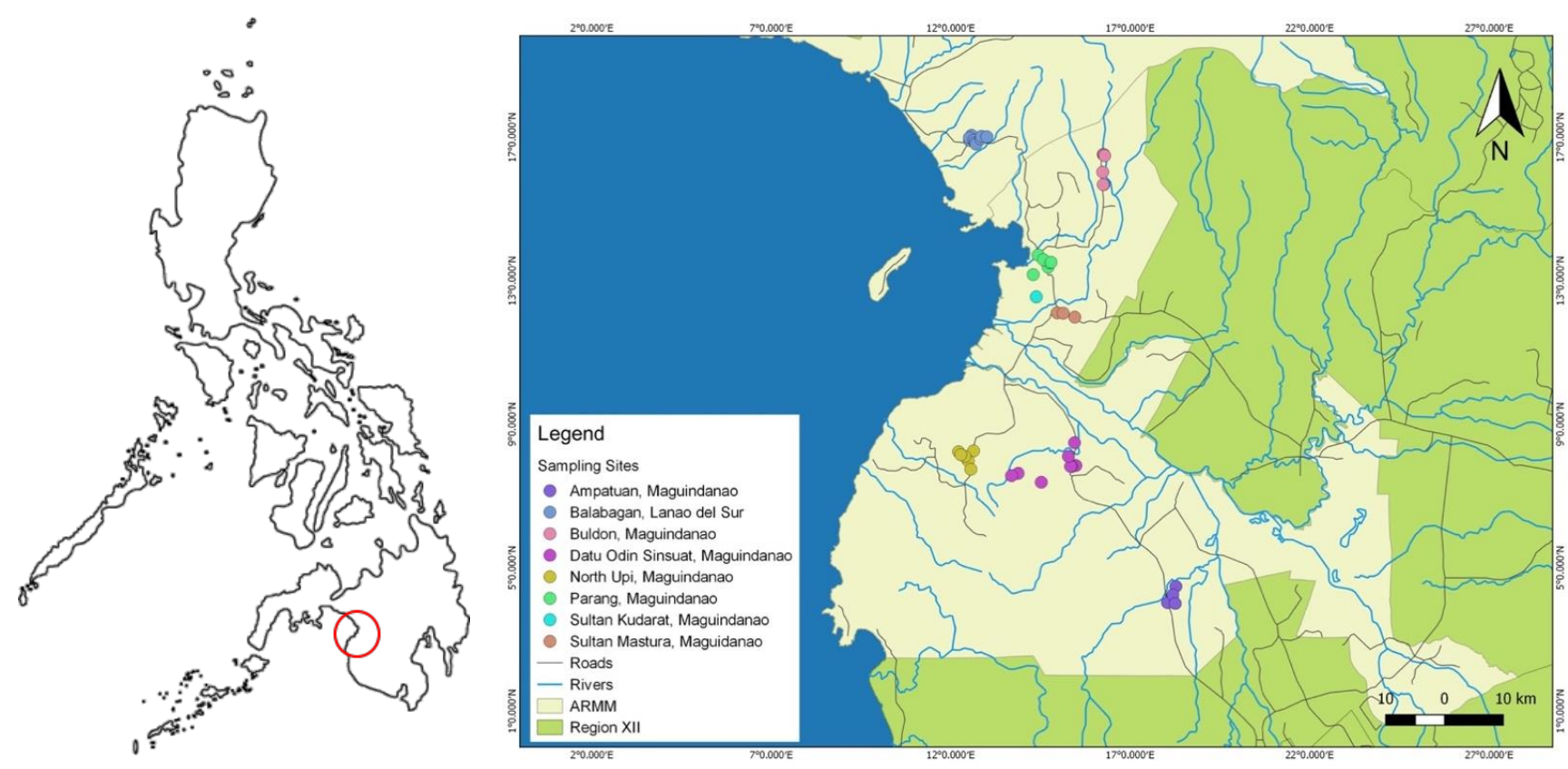

Figure 1. Map of the sampling sites in Bangsamoro Autonomous Region in Muslim Mindanao, the Philippines, showing the locations of the respondents

An on-farm assessment of resources included actual farm visitation and interviews of respondents. Each respondent was interviewed on the species of plants they used as forage.

\section{Data analysis}

Species richness represents the number of forage species provided by each respondent. Each species was ranked based on the frequency of all respondents who mentioned the species. Shannon-Weiner Index was used to determine the diversity of forage species in each site.

\section{RESULTS AND DISCUSSION}

\section{Socio-demographic profile of the respondents}

Table 1 shows the socio-demographic profile of the respondents. Among the 47 respondents, $80 \%$ were male, and $20 \%$ were female. Respondents' age ranged from 1980 years old, with a mean of 40.7. Twenty percent (20\%) of the respondents were elementary graduates, $60 \%$ were high school graduates, and $20 \%$ were college graduates. Most of the respondents were married (98\%), and $2 \%$ were single. Aside from goat raising, $22 \%$ of the respondents have other jobs like employment in Local Government Units (LGU), University, and carpentry work. Others were engaged in crop farming $(66 \%)$, and $12 \%$ primarily depended on goat raising. Regarding herd size, $20 \%$ of the respondents have $>20$ breeder does while $80 \%$ have $5-20$ breeder does. Most respondents stated that they sell their goats for school and emergency expenses. Only a few slaughter their goats for personal consumption during special occasions.
Table 1. Socio-demographic profile of the respondents

\begin{tabular}{llll}
\hline Indicators & & n & $\begin{array}{l}\text { Percent- } \\
\text { age (\%) }\end{array}$ \\
\hline Age & 19-33 years old & 15 & 31 \\
& 34-48 years old & 24 & 51 \\
Mean age & 49 years old and above & 8 & 18 \\
40.7 years old & & \\
Sex & Male & 37 & 80 \\
& Female & 10 & 20 \\
Educational & Elementary Graduate & 9 & 20 \\
attainment & High School Graduate & 29 & 60 \\
& College Graduate & 9 & 20 \\
& Single & 2 & 2 \\
Civil status & Married & 45 & 98 \\
& & & \\
Occupation & Farming & 32 & 66 \\
& Goat & 5 & 12 \\
& Other & 10 & 22 \\
& 5-20 does & 37 & 80 \\
Herd size & $>20$ does & 10 & 20 \\
& & & \\
\hline
\end{tabular}

\section{Species of forages}

Based on the interview results, a total of 17 plant species were used by the respondents as forage. Out of the 17 species, four were used by all respondents as forage, namely para grass (Brachiaria mutica), carabao grass (Paspalum conjugatum), ipil-ipil (Leucaena leucocephala), and kakawate (Gliricidia sepium) (Figure 2). 
Most of the respondents also used malunggay (Moringa oleifera), banana (Musa balbisiana) leaves, stylo (Stylosanthes humilis), langka (Artocarpus heterophyllus) leaves, and centrosema (Centrosema pubescens) (Figure 3).

Among the respondents, less than $20 \%$ were using pinto peanut (Arachis pintoi), barnyard grass (Echinochloa sp.), Napier (Pennisetum purpureum), Guinea grass (Panicum maximum), Indigofera (Indigofera tinctoria), calliandra (Calliandra calothyrsus), katurai (Sesbania grandiflora) and rensonii (Desmodium cinereum) (Figure 4). It was also documented that only a few respondents $(11 \%)$ established some of the aforementioned improved forages. Other respondents collect forages from vegetated areas or tethered goats in rangeland. Improved forages are species of plants commonly cultivated for livestock production.

Most of the respondents practiced tethering in open vegetated areas. The goat consumed other plant species tethered, including Erigeron canadensis, Ageratum conyzoides, Sphagneticola trilobata, and Urena lobata (Figure 5). Identification of these plants was based on the respondents' statement coupled with field observation and the respondents.

There were also issues stated by farmers related to forages. In Buldon (Maguindanao) and Balabagan (Lanao del Sur), C. pubescens (Figure 3-d) were the most common and abundant legumes. However, they seldom use this species since it has been associated with diarrhea cases in goats. In addition, respondents observed more than 60 deaths of a goat after consuming large amounts of Urena lobata (Figure 5-d) in Datu Odin Sinsuat, Maguindanao. According to them, it is the only available plant species, especially during the dry season.

\section{Diversity index}

Table 2 shows the computed diversity index values in each sampling site. The Highest Shannon-Weiner index was recorded in Balabagan, Lanao del Sur (2.369). This was followed by Ampatuan (2.288), Buldon (2.172) and Parang (2.043), all in Maguindanao. Sultan Kudarat, Maguindanao had the lowest Shannon-Weiner diversity index (1.609).

Table 1. Species richness and Shannon-Weiner Index of each sampling site

\begin{tabular}{lcc}
\hline Sampling site & $\begin{array}{c}\text { Species } \\
\text { richness } \\
\text { (n) }\end{array}$ & $\begin{array}{c}\text { Shannon- } \\
\text { Weiner } \\
\text { Index (H) }\end{array}$ \\
\hline Ampatuan, Maguindanao & 10 & 2.288 \\
Buldon, Maguindanao & 9 & 2.172 \\
Datu Odin Sinsuat, Maguindanao & 7 & 1.661 \\
Upi, Maguindanao & 7 & 1.898 \\
Parang, Maguindanao & 9 & 2.043 \\
Sultan Kudarat, Maguindanao & 5 & 1.609 \\
Sultan Amstura, Maguindanao & 7 & 1.872 \\
Balabagan, Lanao del Sur & 15 & 2.369 \\
\hline
\end{tabular}

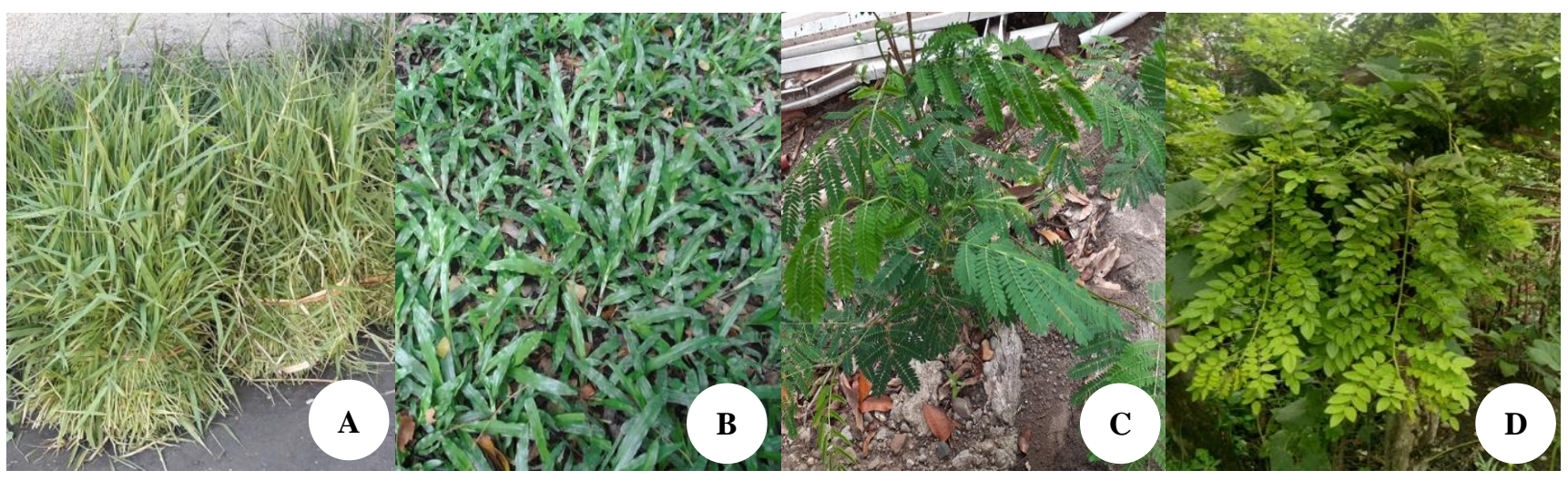

Figure 2. Habit of (A) paragrass (Brachiaria mutica), (B) carabao grass (Paspalum conjugatum), (C) ipil-ipil (Leucaena leucocephala) and (D) kakawate (Gliricidia sepium).

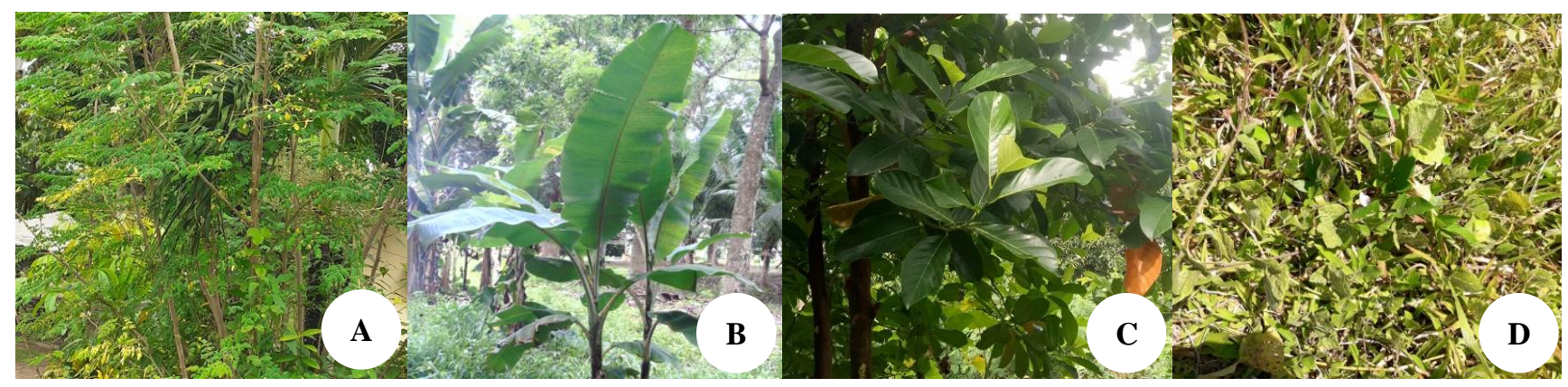

Figure 3. Habit of (A) malunggay (Moringa oleifera), (B) banana (Musa balbisiana), (C) langka (Artocarpus heterophyllus) and (D) centrosema (Centrosema pubescens) 


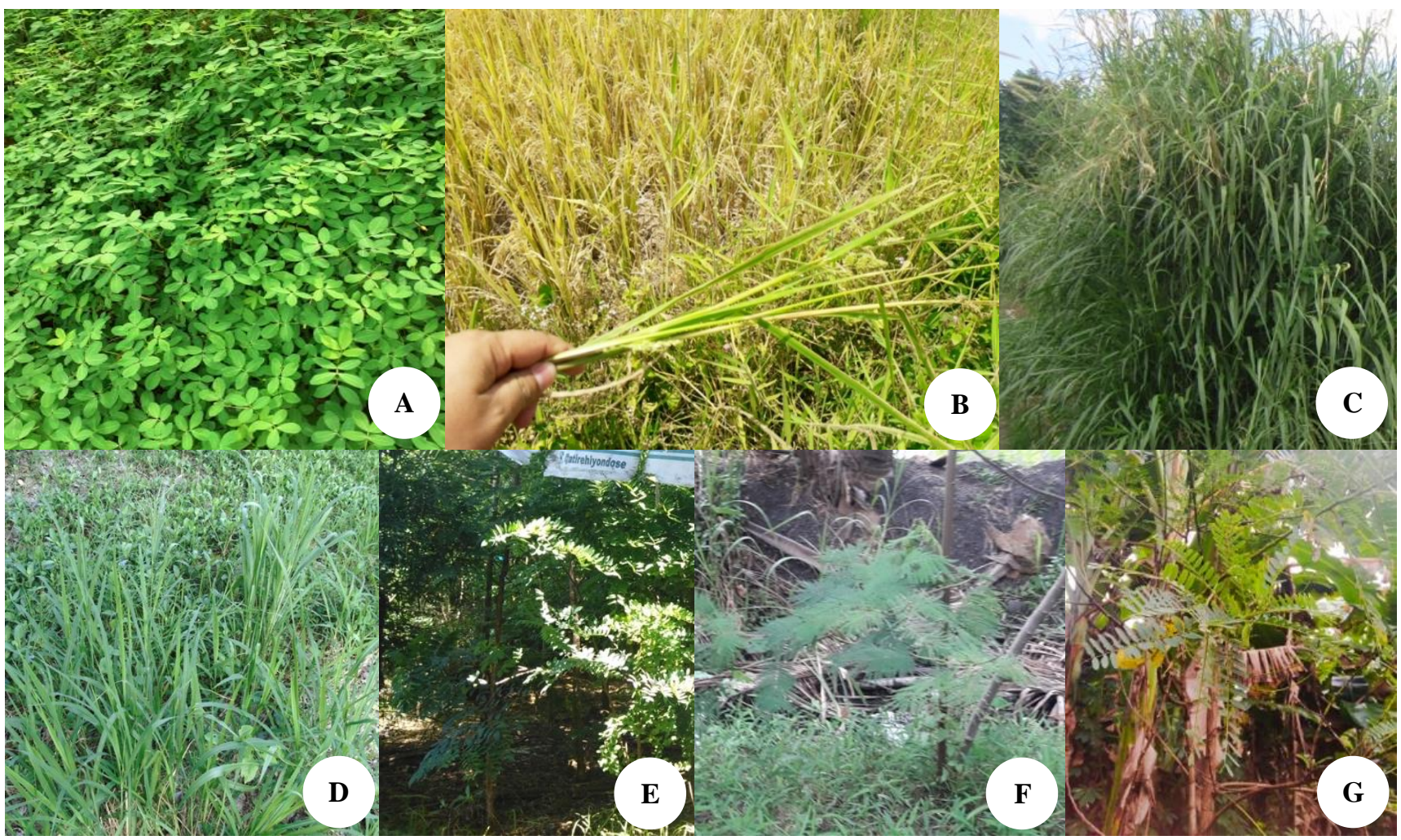

Figure 4. Habit of (A) pinto peanut (Arachis pintoi), (B) barnyard grass (Echinochloa sp.), (C) Napier (Pennisetum purpureum), (D) Guinea grass (Panicum maximum), (E) Indigofera (Indigofera tinctoria), (F) calliandra (Calliandra calothyrsus) and (G) katurai (Sesbania grandiflora)

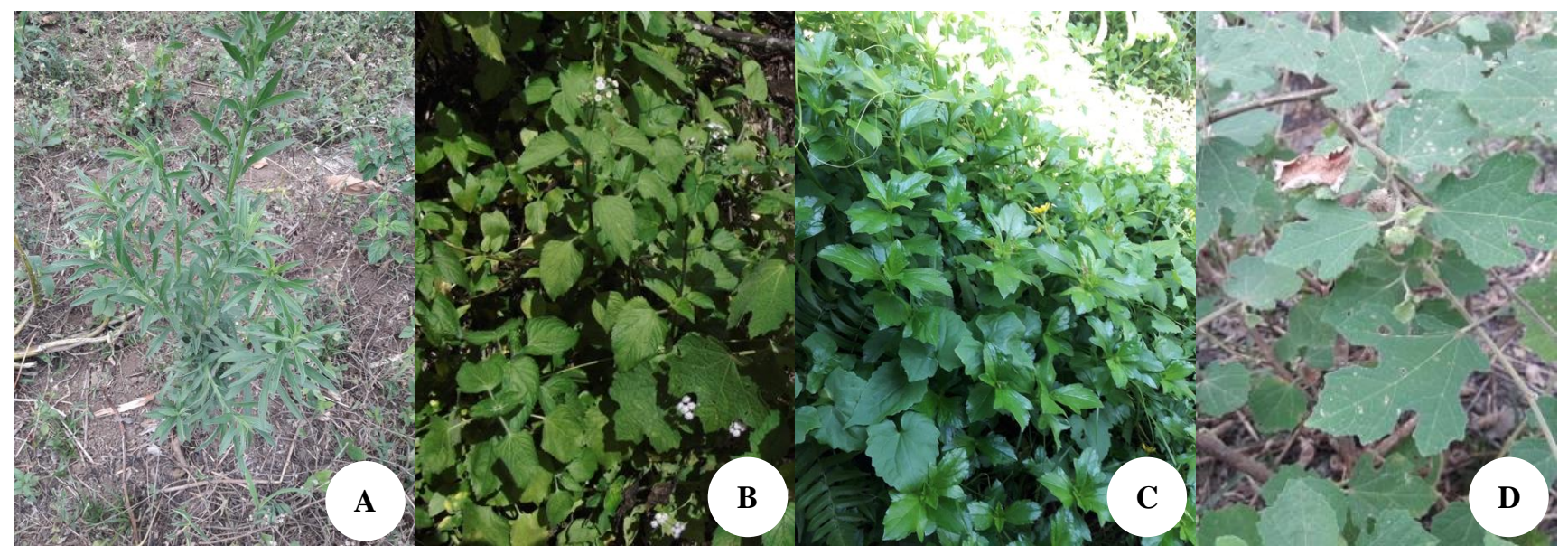

Figure 5. Habit of (A) Erigeron canadensis, (B) Ageratum conyzoides, (C) Sphagneticola trilobata and (D) Urena lobata

\section{Discussion}

It can be noted that forages used by the respondents differ from region to region. However, similarities may be observed, especially species that are well-known as forages. All of the respondents utilized para grass (Brachiaria mutica), carabao grass (Paspalum conjugatum), ipil-ipil (Leucaena leucocephala), and kakawate (Gliricidia sepium). In Fuentes et al.'s (2006) study, these species were also commonly used by conventional goat raisers in the nearby region of Davao (Philippines). In most cases, B. mutica, L. leucocephala, and $G$. sepium are used for cut-and-carry feeding systems, while $P$. conjugatum is grazed by goats in an open field. In the Philippines, Gerpacio and Castillo (1979) established a list of feedstuffs for goat production with their respective nutrient composition. The list includes some forage species like Napier grass (Pennisetum purpureum), para grass (Urochloa mutica), star grass (Cynodon plectostachyus), 
Guinea grass (Panicum maximum), flemingia (Flemingia macrophylla), ipil-ipil (Leucaena leucocephala), Centrosema (Centrosema pubescens), siratro (Phaseolus atropurpureus), calliandra (Calliandra callothyrsus), kakawate (Gliricidia sepium), pigeon pea (Cajanus cajan), mulberry (Morus alba) and rensonii (Desmodium rensonii). Goats are known to relish paragraphs, stargrass, Napier grass, Guinea grass, and Centrosema over-improved tropical grasses and legumes among these forages.

Moreover, Fujihara et al. (2006) evaluated the mineral nutrition of grazing goats and have enumerated some forage species in pasture areas for goats in Luzon. Several species of forages identified include Axonopus compressus, Brachiaria mutica, Cynodon plectostachyus, Eleusine indica, Imperata cylindrical, Pennisetum purpureum, Rottboellia exaltata, Gliciridia sepium, Aeschynomene indica, Calopogonium mucunoides, Centrosema pubescens, Desmodium tortousum, Leucaena leucocephala, and Sesbania sesban.

Among the Brachiaria species, only B. mutica can thrive well in waterlogged areas (Cardoso et al., 2013). The location of sampling areas can explain the availability of this species to all respondents interviewed. Based on the map (Figure 1), most of the sampling areas are located near bodies of water which favors the growth of B. mutica.

Both L. leucocephala and G. sepium are multipurpose forages. Farmers need to select species that can be used in different ways on the farm. These two species are not only protein-rich forage that can be used for ruminants but has other significant uses in the farm, such as fuelwood, fence, live post, shade, and windbreak. In addition, these species are easy to propagate using only stem cuttings (Mangesho et al., 2017). They are also common in open, shaded, and unutilized areas. Leucaena leucocephala is also known to be well-adapted in different environmental conditions in the tropics. It can also maintain green leaf and remain productive throughout a long dry season (Dubeux et al., 2017). On the other hand, Bestil et al. (2014) stated that Paspalum conjugatum has more significant potential as ruminant feed. However, the quantity of forage obtained from the species and its versatility to grow in marginal areas are its limitations when utilized as forage.

Most respondents also used Moringa oleifera, Musa balbisiana leaves, Stylosanthes humilis, Centrosema pubescens, and Artocarpus heterophyllus leaves. In Manh et al.'s (2005) study, M. oleifera can be used as sole feed for goats compared to L. leucocephala. Makkar and Becker (1996) added that Moringa foliage is an excellent and inexpensive protein source with low anti-nutritional factors. Banana leaves can be used as supplemental forage but not as sole forage. It is not enough to supply the nutritional requirements of goats. Although, banana leaves can be an alternative to reduce the weight loss of goats in case of reduction of forage availability, especially during the dry season (Pathoummalangsy and Preston 2008). This agrees with the interview results, wherein most of the respondents stated that banana leaves are utilized as supplemental feed. Stylosanthes humilis and Centrosema pubescens are also used as a protein for goats. Stylo is suited for forage in subhumid tropical and subtropical areas with a marked dry season and is applicable for cut and carry systems (Cook et al., 2005 source). Centrosema pubescens trailing-climbing forage crop with crude protein content ranges from 20 to $26 \%$, usually intercropped with grasses, small tree legumes, and shrubs. In the upland areas of Leyte (Philippines), Artocarpus heterophyllus leaves are commonly fed in goats and have the potential to be supplemental foliage based on in-situ degradation since it may provide more excellent by-pass nutrients for utilization at the intestinal level (Bestil et al. 2014).

It is interesting to note that less than $20 \%$ of the respondents utilize improved species of forages. This result is commonly attributed to two factors: limited land area, expenses for improved pasture establishment, and unavailable planting materials for improved species of forages. Due to limited land area, many respondents practiced a cut and carry system of feeding their animals. Forage establishment bears additional costs for farmers. Prices may include planting materials, maintenance, and even fencing. In the study of Cosadio et al. (2011), although improved pasture establishment should be prioritized, most farmers only utilized open vegetated areas due to these constraints. Some farmers establish improved pastures but use native species. Unable to develop improved pastures with domesticated forage species can also be attributed to the existing knowledge of the respondents. Farmers are generally not aware of whether or not their goats have satisfied the daily nutritional requirements. They have nutritional needs of goats and feeding technology that can boost goat performance (Alcedo et al., 2015).

More than 60 deaths were recorded in Datu Odin Sinsuat, Maguindanao due to consumption of Urena lobata. Rangeland is composed of different species of plants that can be of poor nutritional value and contain toxic compounds. These plants are expected to be abundant, especially during extreme conditions like drought, while other plants cannot survive. In these manners, animals dependent on these plants like goats have no alternatives but to consume what is available in the field. It can be noted that plant poisoning is due to either accidental ingestion of material consumed along with forages or willful consumption of poisonous plants (Mugera 1970). This event is common to livestock, particularly goats, due to their dietary plasticity. Moreover, their capacity to access preferred and desirable plant species is also associated with poisoning events and limited pasture areas, and rangeland results in an increased incidence of animal poisoning (Damiran and Darambazar 2003). Non-conventional forage as a supplement to the poor quality and inadequate grasses during the dry season can also be attributed to plant-related poisoning, common in the topics (Olafadehan 2011). Poisoning events also depend on grazing behavior and animal susceptibility to plant toxins. In most cases, fewer production losses are observed when animals grazed on several species of forages than single species consumption. Moreover, variations in the palatability of plants to animals also affect cases of poisoning (Ralphs and Provenza 1990). Cardiac glycoside, a toxic compound in most animals, is 
present in Urena lobata, which can cause death cases of goats (Fagbohun et al., 2012).

Based on the Shannon-Weinner index, Balabagan had the highest value corresponding to increased diversity. This result can be attributed to the respondents' more increased number of forage species identified and used in the area. This index measures the species abundance and richness, so high diversity in Balabagan, Lanao del Sur (Gaines et al. 1999). In addition, the Shannon diversity index ranges from 1.5 to 3.5 , wherein the computed values in all sampling sites belong to this range which supports the accuracy of the results.

In conclusion, most respondents utilized feed resources available in open vegetated areas. Only a few of them use improved and domesticated species of forages due to limited land area, additional expenses in establishing improved forages, and unavailable planting materials.

\section{REFERENCES}

Alcedo MJ, Ito K, Maeda K. 2015. Stockmanship competence and its relation to productivity and economic profitability: The context of backyard goat production in the Philippines. Asian Australas J Anim Sci 28 (3): 428-434. DOI: 10.5713/ajas.14.0693.

Ambali AR, Bakar AN. 2014. People's awareness on halal foods and products: Potential issues for policy-makers. Procedia- Soc Behav Sci 121: 3-25. DOI: 10.1016/j.sbspro.2014.01.1104.

Bestil LC, Atole AF, Rama J. 2014. Chemical composition and digestibility of in situ common feed resources for ruminants in marginal uplands. Ann Trop Res 3: 179-190. DOI 10.32945/atr36s12.2014.

Bojkovski D, Stuhec I, Kompan D, Zupan M. 2014. The behavior of sheep and goats co-grazing on pasture with different vegetation types in the karst region. J Anim Sci 92 (60): 2752-2758. DOI: 10.2527/jas.20137199.

Cardoso JA, Rincon J, Jimenez JC, Noguera D, Rao I. 2003. Morphoanatomical adaptations to waterlogging by germplasm accessions in a tropical forage grass. AoB Plants 5: 1-14. DOI: 10.1093/aobpla/plt047.

Cook BG, Pengelly BC, Brown SD, Donnelly JL, Eagles DA, Franco MA Hanson J, Mullen BF, Partridge IJ, Peters M, Schultze-Kraft R. 2005 Tropical Forages. CSIRO, DPI \& F (Qld), CIAT and ILRI, Brisbane, Australia.

Cosadio AL, Hebron IU, Ellacer R. 2011. Assessment of Backyard Goat Raising in Claveria, Misamis Oriental, Philippines. Mindanao J Sci Technol 9: 73-86.

Damiran D, Darambazar E. 2003. Toxic Plants of Mongolian Rangelands. Eastern Oregon Agricultural Research Station Union, Oregon State University, Oregon, U.S.A

Dubeux Jr, JCB, Muir J, Apolinarion VXO, Nair PKR, Lira MA, Sollenberger LE. 2017. Tree legumes: an underexploited resource in warm-climate silvopasture. Braz J Anim Sci 46 (8): 689-703. DOI: 10.1590/s1806-92902017000800010.

Ebong C. 1995. Acacia nilotica, Acacia seyal, and Sesbania sesban as supplements to tef (Eragrostis tef) straw fed to sheep and goats. Small Ruminant Res 18: 233-238. DOI: 10.1016/0921-4488(95)00676-6.

E-Halal Organization. 2010. Your ultimate guide to the world of Halal food. www.islamicpopulation.com

Fagbohun ED, Asare RR, Egbebi AO. 2012. Chemical composition and antimicrobial activities of Urena lobata L. (Malvaceae). J Med Plant Res 6 (12): 2256-2260. DOI: 10.5897/JMPR09.233.

Farouk MM, Pufpaff KM, AMIR M. 2016. Industrial halal meat production and animal welfare: A review. Meat Sci 120: 60-70. DOI: 10.1016/j.meatsci.2016.04.023

Fuentes A, Revilla NN, Tanduyan R, Subaldo M, Natad V, Tantano R. 2006. Goat production and marketing practices in Davao del Sur.
PCARRD [Philippine Council for Agriculture, Forestry and Natural Resources Research and Development] Highlights 2005. [Philippines]

Fujihara T, Serra AB, Serra SD, Orden EA. 2006. Mineral nutrition of grazing goats in Luzon Island, Philippines. Bull Fac Life Env Sci Shimane Univ 11: 19-34.

Gaines WL, Harrod JR, Lehkuhl JF. 1999. Monitoring Biodiversity: Quantification and Interpretation. General Technical Report PNWGTR-443, USDA Forest Service, Pacific North-West Research Station. DOI: 10.2737/PNW-GTR-443.

Gerpacio AL, Castillo LS. 1979. Nutrient composition of some Philippine feedstuffs. Extension Division, Department of Animal Science, College of Agriculture, University of the Philippines Los Baños.

Ibrahim M. 2011. Consumer willingness to pay a premium for Halal goat meat: A case from Atlanta, Georgia. J Food Distrib Res 42 (1): 72-76.

Krueger WM, Sharp LA. 1978. Management approaches to reduce livestock losses from poisonous plants on rangeland. J Range Manag 31 (5): 347-350. DOI: $10.2307 / 3897357$.

Leng RA. 1997. Tree legumes in ruminant nutrition. FAO Animal Production and Health Paper. 139, FAO, Rome.

Makkar HPS, Becker K. 1996. Nutritional value and anti-nutritional components of whole and extracted Moringa oleifera leaves. Anim Feed Sci Technol 63: 211-228. DOI: 10.1016/S0377-8401(96)010231.

Makkar HPS. 2003. Effects and fate of tannins in ruminant animals, adaptation to tannins, and strategies to overcome detrimental effects of feeding tannin-rich feeds. Small Ruminant Res 49: 241-256. DOI: 10.1016/S0921-4488(03)00142-1.

Mangesho WE, Kurwijila LR, Shirima DD. 2017. Leguminous fodder trees as protein source and carbon sink in smallholder dairy production systems in Muheza District, Tanga Region, Tanzania. Livest Res Rural Dev Volume 29, Article \#186. http: //www.lrrd.org/lrrd29/10/wman29186.html

Manh LH, Nhut N, Dung X, Phung Ngoi T. 2005. Introduction and evaluation of Moringa oleifera for biomass production and as feed for goats in the Mekong Delta. Livest Res Rural Dev Volume 17, Article \#104. http: //www.lrrd.org/lrrd17/9/manh17104.htm

Mkhize N, Scogings P, Nsahlai I, Dziba L. 2014. Diet selection of goats depends on season: roles of plant physical and chemical traits. Afr J Range For Sci 31 (3): 209- 214. DOI: 10.2989/10220119.2014.901417.

Mugera GM. 1970. Phytolacca dodecandra L'Herit toxicity in livestock in Kenya. Bull Epizoot Dis Afr 18: 41-43.

Naanep N, Velasco N, Tayab C, Jordan R, Alo A.M. 2009. Benchmarking of Halal goat production and processing practices in Region XII. Philippine J Vet Anim Sci 28 (2): 177-186.

Nakyinsige K, Che Man, YB, Sazili AQ. 2012. Halal authenticity issues in meat and meat products. Meat Sci 91: 207-214. DOI: 10.1016/j.meatsci.2012.02.015.

Nampanzira DK, Kabasa JD, Nalule SA, Nakalembe I, Tabuti JR. 2015. Characterization of the goat feeding system among rural smallholder farmers in the semi-arid regions of Uganda. Springer Plus 4: 188. DOI: 10.1186/s40064-015-0961-3.

Olafadehan OA. 2011. Changes in haematological and biochemical diagnostic parameters of Red Sokoto goats fed tannin-rich Pterocarpus erinaceus forage diets. Vet Archiv 81: 471-483.

PathoummalangsyK, Preston TR. 2008. Effects of supplementation with rumen fermentable carbohydrate and sources of 'bypass' protein on feed intake, digestibility, and $\mathrm{N}$ retention in growing goats fed a basal diet of foliage of Tithonia diversifolia. Livest Res Rural Dev Volume 20 , http://www.lrrd.org/lrrd20/supplement/kham20076.htm

Ralphs MH, Provenza FD. 1990. Minimizing toxic plant losses through behavior modification. Proceedings, West Texas Toxic Plant Symposium. Ft. Stockton, Texas.

Schlecht E, Sangaré M, Becker K. 1999. Supplementation of Zebu cattle grazing Sahelian pasture. I. Diet selection and intake. J Agric Sci 133: 69-81. DOI: 10.1017/S002185969900667X.

Silanikove N, Gilboa N, Perevolotsky A, Nitsan Z. 1996. Goats fed tannin-containing leaves do not exhibit toxic syndromes. Small Ruminant Res 21: 195-201. DOI: 10.1016/0921-4488(95)00833-0. 